\title{
ISOLATION AND CHARACTERIZATION OF ZYMOMONAS MOBILIS MUTANT DEFECTIVE IN PHOSPHATIDYLETHANOLAMINE N-METHYLTRANSFERASE
}

\author{
YASUTAKA TAHARA,* TOMOYUKI YAMASHITA, ATSUSHI SOGABE, \\ AND YOSHIHIRO OGAWA \\ Department of Applied Biological Chemistry, Faculty of Agriculture, \\ Shizuoka University, Shizuoka 422, Japan
}

(Received June 20, 1994; Accepted August 19, 1994)

\begin{abstract}
Two mutants of Zymomonas mobilis defective in phosphatidylethanolamine $\mathrm{N}$-methyltransferase have been isolated. One mutant was completely defective in all of the three $\mathrm{N}$-methyltransferase activities dependent on phosphatidylethanolamine, phosphatidyl-N-monomethylethanolamine and phosphatidyl-N,N-dimethylethanolamine, respectively. The other was a leaky mutant in which the three enzyme activities were all equally reduced to $3.4-6.7 \%$ of those in the parent strain. Two revertants were derived from the leaky mutant, and in both all three enzyme activities were restored to nearly the same levels as those in the wild-type strain.
\end{abstract}

The PE N-methyltransferase system, which forms phosphatidylcholine from phosphatidylethanolamine via the two N-methylated intermediates, PMME and PDME, has been found in various membranes of not only mammalian tissues (2), but also fungi (16) and yeasts (21). An interesting problem concerning the pathway is the number of enzymes which participate in the three-step methylation from PE to PC. The participation of two distinct enzymes in the pathway was first reported in Neurospora crassa by isolating two types of mutant strains (16). Hirata et al. reported that possibly two different enzymes were involved in the methylation pathway in mammalian tissues (8). The participation of two enzymes was also demonstrated in experiments using mutant strains of Saccharomyces cerevisiae (7, 22,23). The two distinct $\mathrm{N}$-methyltransferase genes were cloned by Kodaki and Yamashita (10). In contrast, a single enzyme is responsible for the three-step

* Address reprint requests to: Dr. Yasutaka Tahara, Department of Applied Biological Chemistry, Faculty of Agriculture, Shizuoka University, 836 Ohya, Shizuoka 422, Japan.

Abbreviations: PE, phosphatidylethanolamine; PMME, phosphatidyl-N-monomethylethanolamine; PDME, phosphatidyl-N,N-dimethylethanolamine; PC, phosphatidylcholine; AdoMet, Sadenosyl-L-methionine; NTG, N-methyl-N'-nitro-N-nitrosoguanidine. 
methylation in the rat liver, and the $\mathrm{N}$-methyltransferase has been purified $(12,13$, 15). However, a few cases have been reported on the PE N-methyltransferase system in bacterial cells: Agrobacterium tumefaciens (9), Hyphomicrobium vulgrae (6) and Rhodopseudomonas spheroides (5). It is probably because PC is a rare component of bacterial phospholipids (1), and also the number of enzymes catalyzing the pathway has not yet been clarified.

Previously, we reported the purification of a PE N-methyltransferase which catalyzed all the three-step methylation to homogeneity from the mernbrane fraction of Zymomonas mobilis (19). Subsequently, we have isolated Z. mobilis mutants defective in the PE N-methyltransferase, which are described in this paper.

\section{MATERIALS AND METHODS}

Organism and cultivation. A methionine auxotroph S'T44 (20), derived from Zymomonas mobilis IFO 13756, was used as a parent strain. Cells were cultured statically at $30^{\circ} \mathrm{C}$ in GYP medium containing $2 \%(\mathrm{w} / \mathrm{v})$ glucose, $0.3 \%(\mathrm{w} / \mathrm{v})$ yeast extract and $0.5 \%(\mathrm{w} / \mathrm{v})$ peptone at $\mathrm{pH} 5.5$. Growth was monitored by measurement of the absorbance at $660 \mathrm{~nm}$.

$P E N$-methyltransferase assay. The membrane fraction of the organism was prepared as described previously (19), and used for the enzyme assay. The $\mathrm{N}$-methyltransferase activities dependent on PE, PMME and PDME were determined by measuring the incorporation of the methyl groups from AdoMet into PMME, PDME and PC, respectively. The assay mixture contained $1.36 \mu \mathrm{M}$ [methyl $-{ }^{14} \mathrm{C}$ ]AdoMet $(2.18 \mathrm{MBq} / \mu \mathrm{mol}), 58 \mathrm{nmol} / \mathrm{ml} \mathrm{PE}$, PMME or PDME, 100 mM Tris-HCl buffer (pH 8.5), $10 \mathrm{~mm}$ L-cysteine, 10\% (w/v) glycerol, $0.04 \%(\mathrm{w} / \mathrm{v})$ Triton X-100 and the membrane fraction in a total volume of $1.0 \mathrm{ml}$. The reaction was carried out at $30^{\circ} \mathrm{C}$ for $20 \mathrm{~min}$ and terminated by the addition of $2.5 \mathrm{ml}$ of $1 \mathrm{~N}$ $\mathrm{HCl}$. The lipids in each mixture were extracted using the method of Bligh and Dyer (3), and separated by thin-layer chromatography using a solvent system of chloroform/methanol/water ( $65: 25: 4$, by vol.). The radioactive lipids were visualized with $I_{2}$ vapor, scraped into vials and their radioactivities were counted in a toluene scintillation solution. Enzyme activity was expressed as pmol of methyl- ${ }^{14} \mathrm{C}$ transferred phospholipids/min. However, since the PE and PMME-dependent activities were involved in further methylation to PDME and PC, and to PC, respectively, the two enzyme activities were calculated as the total radioactivities of PMME + 1/2 PDME + 1/3 PC, and PDME + 1/2 PC, respectively, according to the method of Schneider and Vance (17). Membrane protein was determined using the method of Bradford (4) with bovine serum albumin as a standard, after solubilization with deoxycholate.

Isolation of a mutant defective in PE N-methyltransferase. The parent strain ST44 (20) was cultured overnight in GYP medium and mutagenized with $50 \mu \mathrm{g}$ $\mathrm{NTG} / \mathrm{ml}$ for $1 \mathrm{~h}$ at $30^{\circ} \mathrm{C}$ under standard conditions (11). The cells were spread on an agar plate of GYP medium, and grown at $30^{\circ} \mathrm{C}$ for 3 days at a density of about 
200 colonies/plate. The colonies were transferred to a filter paper (Whatman No. 42), which was then treated with lysozyme and EDTA, and subjected to three cycles of freezing and thawing, according to the method of Raetz (14). The assay of PE N-methyltransferase activity in the colonies was carried out on the filter paper, in a Petri dish for $1 \mathrm{~h}$ at $30^{\circ} \mathrm{C}$ in $1.0 \mathrm{ml}$ of assay mixture containing $1.7 \mu \mathrm{M}$ [methyl- ${ }^{14} \mathrm{C}$ ]AdoMet $(2.18 \mathrm{MBq} / \mu \mathrm{mol}), 116 \mathrm{nmol} / \mathrm{ml}$ PMME, $100 \mathrm{mM}$ Tris- $\mathrm{HCl}$ buffer (pH 8.5), $10 \mathrm{~mm}$ L-cysteine, $10 \%(\mathrm{w} / \mathrm{v})$ glycerol and $0.04 \%(\mathrm{w} / \mathrm{v})$ Triton $\mathrm{X}$ 100. The reaction was stopped by transferring the paper to ice-cold $20 \%(\mathrm{w} / \mathrm{v})$ trichloroacetic acid. The filter paper was washed thoroughly with ice-cold 5\% (w/v) trichloroacetic acid, autoradiographed and then stained with Coomassie brilliant blue R250. Using this procedure, more than $90 \%$ of the radioactivity generated on the filter paper was recovered in the enzymatic products of PDME and PC, despite no addition of the energy poison which was originally used by Raetz (14). Mutant selection was performed by comparison of a stained replica with the corresponding autoradiogram.
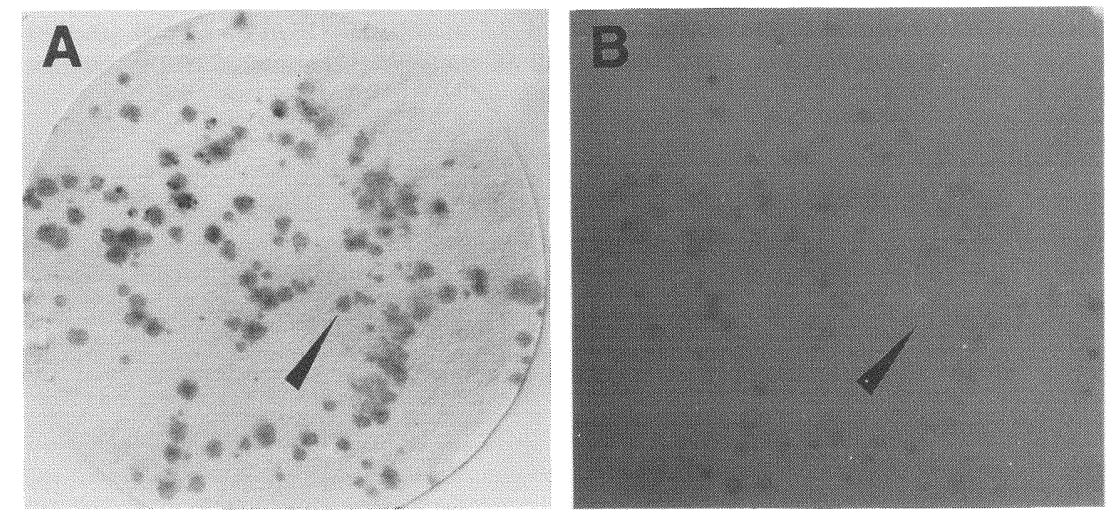

Fig. 1. Selection of a mutant defective in PE N-methyltransferase by the colony autoradiographic assay.

Panel A, a filter paper stained with Coomassie blue; panel B, the corresponding autoradiogram. An arrow shows the position of the colony giving a fainter spot than its neighbors on the autoradiogram.

Table 1. N-Methyltransferase activities dependent on PE, PMME and PDME of the membrane fractions of the parent, mutant and revertant strains.

\begin{tabular}{lccc}
\hline \multirow{2}{*}{ Strain } & \multicolumn{3}{c}{ Specific activity $(\mathrm{pmol} / \mathrm{min} / \mathrm{mg}$ protein) dependent on } \\
\cline { 2 - 4 } & PE & PMME & PDME \\
\hline ST44 & 0.26 & 19.00 & 16.32 \\
YT03 & 0.00 & 0.00 & 0.00 \\
OT310 & 0.01 & 0.69 & 0.82 \\
R310 & 0.26 & 18.06 & 16.65 \\
R311 & 0.23 & 19.05 & 16.53 \\
\hline
\end{tabular}


Isolation of the revertant. The mutant strain OT310 was mutagenized with 50 $\mu \mathrm{g} / \mathrm{ml}$ NTG using the same condition as described above. The mutagenized cells were spread on an agar plate of GYP medium after segregation. Revertant selection was carried out using the same colony autoradiographic procedure, except for the selection of colonies clearly showing radioactivity on the autoradiogram.

Phospholipid analysis. Phospholipids were determined by counting their radi-

Table 2. Incorporation of methyl groups from [methyl- $\left.{ }^{14} \mathrm{C}\right]$ methionine into PMME, PDME and PC of the parent, mutant and revertant strains.

\begin{tabular}{lrrr}
\hline & \multicolumn{3}{c}{ Radioactivity (counts/min) in } \\
\cline { 2 - 4 } Strain & PMME & PDME & PC \\
\hline ST44 & 714 & 5,814 & 18,299 \\
YT03 & 48 & 52 & 63 \\
OT310 & 237 & 746 & 548 \\
R310 & 658 & 5,245 & 15,310 \\
R311 & 580 & 6,761 & 17,523 \\
\hline
\end{tabular}

Cells were grown at the middle logarithmic phase, collected by centrifugation, and then suspended in GYP medium to give an absorbance of 0.5 at $660 \mathrm{~nm}$. $10 \mu 1$ of $2.1 \mathrm{mM}$ [methyl $-{ }^{14} \mathrm{C}$ ]methionine $(1.75 \mathrm{MBq} / \mu \mathrm{mol})$ was added to $5.0 \mathrm{ml}$ of the cell suspension and the mixture was incubated at $30^{\circ} \mathrm{C}$ for $2 \mathrm{~h}$.
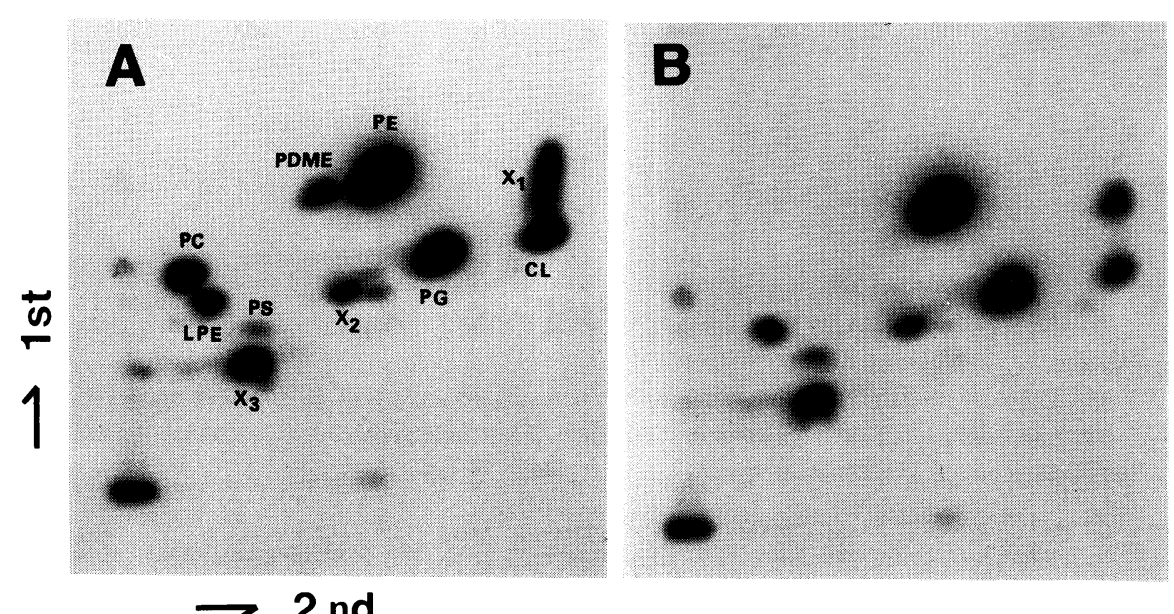

Fig. 2. Two-dimensional autoradiograms of $\left[{ }^{32} \mathrm{P}\right]$ phospholipids from the parent ST44 (A) and mutant YT03 (B) strains.

Cells were labelled with $\left[{ }^{32} \mathrm{P}\right]$ orthophosphate for $8 \mathrm{~h}$ during the logarithmic phase. The extractable lipids were subjected to two-dimensional silica gel thin-layer chromatography, followed by autoradiography as described in MATERIALS AND MethodS. Phospholipids identified were cardiolipin (CL), phosphatidylglycerol (PG), phosphatidylserine (PS), lysophosphatidylethanolamine (LPE), PE, PDME and PC. Unidentified lipids are shown as $\mathrm{X}_{1}, \mathrm{X}_{2}$ and $\mathrm{X}_{3}$. 
oactivities after labelling cells with $\left[{ }^{32} \mathrm{P}\right]$ orthophosphate. Phospholipids were extracted by the method of Bligh and Dyer (3) and then separated by twodimensional silica gel $\mathrm{G}$ thin-layer chromatography using chloroform/methanol/water (14:6:1, by vol.) as the first solvent system and chloroform/methanol/acetic acid (13:5:2, by vol.) as the second. Each phospholipid was visualized on the autoradiogram, scraped into a vial and then the radioactivity was counted. The phospholipids PMME, PDME and PC were also labelled with methyl groups from [methyl- ${ }^{14} \mathrm{C}$ ]methionine, and separated by one-dimensional thin-layer chromatography using a solvent system of chloroform/methanol/water $(65: 25: 4$, by vol.).

Materials. [Methyl- ${ }^{14} \mathrm{C}$ ]AdoMet $(2.18 \mathrm{MBq} / \mu \mathrm{mol})$ and $\left[\right.$ methyl- $\left.{ }^{14} \mathrm{C}\right]$ methionine (1.75 MBq/ $/ \mu \mathrm{mol})$ were purchased from New England Nuclear (Boston, MA, U.S.A.). $\left[{ }^{32}\right.$ P] orthophosphate was from the Japan Atomic Energy Research Institute (Ibaraki, Japan). Phospholipids were products of Sigma Chemical Co. (St. Louis, MO, U.S.A.). All other chemicals were of analytical grade.

\section{RESULTS}

\section{Isolation and characterization of the mutants}

In order to isolate the mutants by the colony autoradiographic screening, PMME-dependent N-methyltransferase activity was employed because this activity was the highest of the three phospholipid methylation enzyme activities in $Z$. mobilis (19). A typical stained replica and the corresponding autoradiogram of the screening method are shown in Fig. 1. From among about 12,000 colonies assayed on the filter papers, two mutants defective in PE N-methyltransferase, designated as YT03 and OT310, were isolated. Table 1 shows the three enzyme activities of the PE N-methyltransferase in parent strain ST44 and the mutant strains. In strain YT 03, the none of the three activities of PE-, PMME- and PDME-dependent Nmethyltransferase were detected. The other mutant, OT310, was a leaky mutant, and the three enzyme activities were all equally reduced to $3.4-6.7 \%$ of those in the parent strain. In vivo analysis of the methylation pathway was also performed as to the incorporation of methyl groups from [methyl- ${ }^{14} \mathrm{C}$ ] methionine into the PMME, PDME and PC, and the results were in good agreement with those for the enzyme activities (Table 2). The phospholipid compositions of the parent and mutant strains were determined by labelling cells with $\left[{ }^{32} \mathrm{P}\right]$ orthophosphate. Figure 2 shows the two-dimensional thin-layer autoradiograms of ${ }^{32} \mathrm{P}$-labelled lipids from parent ST44 and mutant YT03. Radioactive spots of PDME and PC on the autoradiogram of mutant YT03 were completely absent. On the contrary, the PE content of the mutant was increased by about $20 \%$ in comparison with that of the parent cells (Table 3). A marked decrease in PDME and PC was also found in the mutant OT310 (Table 3).

\section{Isolation and characterization of the revertants}

Isolation of the revertants was attempted to determine whether or not the 
Table 3. Phospholipid compositions of the parent, mutant and revertant strains.

\begin{tabular}{lcccccccc}
\hline & \multicolumn{7}{c}{ Composition (\% of total ${ }^{32}$ P) } \\
\cline { 2 - 8 } Strain & CL & PG & PS & LPE & PE & PDME & PC & $\begin{array}{c}\text { Unidentified } \\
\text { lipids }\end{array}$ \\
\hline ST44 & 7.6 & 22.0 & 0.6 & 4.1 & 51.3 & 1.2 & 5.3 & 8.8 \\
YT03 & 2.3 & 24.2 & 0.4 & 1.4 & 62.2 & 0.0 & 0.0 & 9.9 \\
OT310 & 4.6 & 23.9 & 0.7 & 4.0 & 55.3 & 0.1 & 0.2 & 11.2 \\
R310 & 5.1 & 22.4 & 0.8 & 3.6 & 53.3 & 1.2 & 4.2 & 9.4 \\
R311 & 4.5 & 21.4 & 0.8 & 3.5 & 52.7 & 1.2 & 4.3 & 11.6 \\
\hline
\end{tabular}

Abbreviations for the phospholipids are the same in Fig. 2.

defects of the three enzyme activities in the mutant strains were caused by mutation of the same gene. Two revertants, R310 and R311, were isolated from the mutant OT310, after NTG treatment with the same isolation procedure except for the selection of colonies showing radioactivity on the autoradiogram. Revertants were obtained at a frequency of $4 \times 10^{-4}$. The three $\mathrm{N}$-methyltransferase activities in both revertant strains were restored to nearly the same levels as those in the wild-type strain (Table 1). Phospholipid analysis of both revertants also indicated good recovery in PDME and PC (Table 3).

\section{DISCUSSION}

The mutant strain YT03 described here was completely defective in all the three N-methyltransferase activities (Table 1). Revertants R310 and R311 derived from mutant OT310 recovered all three enzyme activities to nearly the same levels as the wild-type strain (Table 1). Simultaneous defects and recoveries in the three enzyme activities in the mutants and the revertants are likely to be caused by mutation of the same structural gene or regulatory gene concerning the PE $\mathrm{N}$-methyltransferase.

$\mathrm{PC}$ is known to be synthesized by two routes, namely the methylation pathway and the CDP-choline pathway, in eukaryotic cells including fungi and yeasts (2). On the other hand, the CDP-choline pathway of prokaryotic cells has not yet been demonstrated, although attempts have been made by ourselves and by Sherr and Law (18) to detect it in Agrobacterium tumefaciens. The PE N-methyltransferasedefective mutant, YT03, completely lacked PC (Table 3). This probably indicates that $\mathrm{PC}$ is synthesized only by the methylation pathway in $Z$. mobilis.

Two types of mutants defective in PE-N-methylation pathway have been isolated as choline auxotrophs from Neurospora crassa (16) and Saccharomyces cerevisiae $(7,22,23)$ : One is defective in PE-dependent $\mathrm{N}$-methyltransferase and the other in PMME-dependent N-methyltransferase, which suggests that the PE-Nmethylation pathway in those organisms is catalyzed by two distinct enzymes. Two $\mathrm{N}$-methyltransferase genes of $S$. cerevisiae were cloned: One gene encoding the enzyme catalyzing the first methylation of PE to PMME, and the other gene 
encoding a single enzyme which catalyses the three-step methylation from PE to PC (10). The latter enzyme seems to be similar in its substrate specificity to the PE $\mathrm{N}$-methyltransferase from Z. mobilis (19). It would be of interest to examine the relationship between the enzymes, when considering the biogenesis of PE Nmethyltransferase.

\section{REFERENCES}

1) Ambron, R. T. and Pieringer, R. A., Phospholipids in micro-organisms. In Form and Function of Phospholipids, ed. by Ansell, G. E., Hawthorne, J. N., and Dawson, R. M. C., Elsevier Sci. Publ., Amsterdam (1976), p. 289-331.

2) Ansell, G. B. and Spanner, S., Phosphatidylserine, phosphatidylethanolamine and phosphatidylcholine. In Phospholipids, ed. by Hawthorne, J. N. and Ansell, G. B., Elsevier Biomedical Press, Amsterdam (1982), p. 1-49.

3) Bligh, E. G. and Dyer, W. J., A rapid method of total lipid extraction and purification. Can. J. Biochem. Physiol., 37, 891-917 (1959).

4) Bradford, M. M., A rapid and sensitive method for the quantitation of microgram quantities of protein utilizing the principles of protein-dye binding. Anal. Biochem., 72, 248-254 (1976).

5) Cain, B. D., Donohue, T. J., Shepherd, W. D., and Kaplan, S., Localization of phospholipid biosynthetic enzyme activities in cell-free fractions derived from Rhodopseudomonas spheroides. $J$. Biol. Chem., 259, 942-948 (1984).

6) Goldfine, H. and Hagen, P. O., N-Methyl groups in bacterial lipids III. Phospholipids of Hyphomicrobia. J. Bacteriol., 95, 367-375 (1968).

7) Greenberg, M. L., Klig, L. S., Letts, V. A., Loewy, B. S., and Henry, S. A., Yeast mutant defective in phosphatidylcholine synthesis. J. Bacteriol., 153, 791-799 (1983).

8) Hirata, F., Vivoros, O. H., Diliberto, E. J., and Axelrod, J., Identification and properties of two methyltransferase in conversion of phosphatidylethanolamine to phosphatidylcholine. Proc. Natl. Acad. Sci. U.S.A., 75, 2348-2352 (1978).

9) Kaneshiro, T. and Law, J. H., Phosphatidylcholine synthesis in Agrobacterium tumefaciens. J. Biol. Chem., 239, 1705-1713 (1964).

10) Kodaki, T. and Yamashita, S., Yeast phosphatidylethanolamine methylation pathway: Cloning and characterization of two distinct methyltransferase genes. J. Biol. Chem., 262, 15428-15435 (1987).

11) Miller, J. H., Nitrosoguanidine mutagenesis. In Experiments in Molecular Genetics, ed. by Miller, J. H., Cold Spring Harbor Laboratory, New York (1972), p. 125-129.

12) Pajares, M. A., Alemany, S., Varela, I., Cao, M., and Mato, J. M., Purification and photoaffinity labelling of lipid methyltransferase from rat liver. Biochem. J., 223, 61-71 (1984).

13) Pajares, M. A., Villalba, M., and Mato, J. M., Purification of phospholipid methyltransferase from rat liver microsomal fraction. Biochem. J., 237, 699-705 (1986).

14) Raetz, C. R. H., Isolation of Escherichia coli mutants defective in enzymes of membrane lipid synthesis. Proc. Natl. Acad. Sci. U.S.A., 72, 2274-2278 (1975).

15) Ridgway, N. D. and Vance, D. E., Purification of phosphatidylethanolamine N-methyltransferase from rat liver. J. Biol. Chem., 262, 17231-17239 (1987).

16) Scaborough, G. A. and Nyc, J. F., Methylation of ethanolamine phosphatides of Neurospora crassa. J. Biol. Chem., 242, 238-242 (1976).

17) Schneider, W. J. and Vance, D. E., Conversion of phosphatidylethanolamine to phosphatidylcholine in rat liver. J. Biol. Chem., 254, 3886-3891 (1979).

18) Sherr, S. I. and Law, J. H., Phosphatidylcholine synthesis in Agrobacterium tumefaciens. J. Biol. Chem., 240, 3760-3765 (1965). 
19) Tahara, Y., Ogawa, Y., Sakakibara, T., and Yamada, Y., Purification and characterization of phosphatidylethanolamine N-methyltransferase from Zymomonas mobilis. Agric. Biol. Chem., 51, 1425-1430 (1987).

20) Tahara, Y., Yamashita, T., Kondo, M., and Yamada, Y., Isolation of Zymomonas mobilis mutant deficient in tetrahydroxybacteriohopane biosynthesis. Agric. Biol. Chem., 52, 3189-3190 (1988).

21) Wachter, C. J., Steiner, M. R., and Lester, R. L., Regulation of phosphatidylcholine biosynthesis by the methylation pathway in Saccharomyces cerevisiae. J. Biol. Chem., 244, 3419-3424 (1969).

22) Yamashita, S. and Oshima, A., Regulation of phosphatidylethanolamine methyltransferase level by myo-inositol in Saccharomyces cerevisiae. Eur. J. Biochem., 104, 611-616 (1980).

23) Yamashita, S., Oshima, A., Nikawa, J., and Hosaka, K., Regulation of the phosphatidylethanolamine methylation pathway in Saccharomyces cerevisiae. Eur. J. Biochem., 128, 589-595 (1982). 